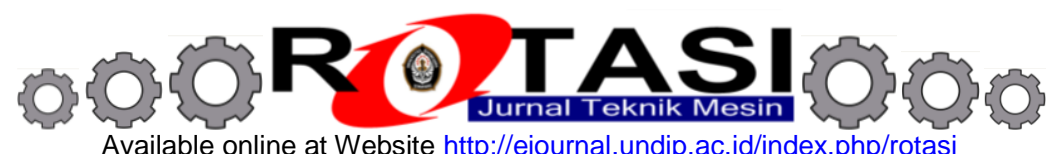

\title{
ANALISIS KERUSAKAN DAN PERBAIKAN OIL PUMP STEAM TURBINE 32-K-101-P1-T DALAM PLATFORMING UNIT-NAPHTA PROCESSING UNIT (NPU)
}

\author{
*Norman Iskandar, Ardha Ridho Pangeran \\ Departemen Teknik Mesin, Fakultas Teknik, Universitas Diponegoro \\ Jl. Prof. Sudharto, SH, Tembalang, Semarang 50275 \\ *E-mail: norman.mesin@gmail.com
}

\begin{abstract}
ABSTRAK
Oil pump steam turbine (OPST) adalah sebuah turbin uap jenis impuls yang digerakan oleh medium pressure steam (MPS) dengan tekanan $15-21 \mathrm{~kg} / \mathrm{cm}^{2} \mathrm{G}$ dan temperatur kerja $250-370{ }^{\circ} \mathrm{C}$. Uap ekstrasi dari turbin uap adalah low pressure steam (LPS) dengan tekanan $3.8-6.3 \mathrm{~kg} / \mathrm{cm}^{2} \mathrm{G}$. Dalam proses perawatannya, OPST diinspeksi setiap 2 minggu sekali dengan melihat kondisi oli, trending getaran, dan putaran poros turbin. Pada saat operasi OPST mengalami kenaikan vibrasi yang melebihi batas toleransi (vs $2.82 \mathrm{~mm} / \mathrm{s}$ ) dan keruhnya oli pelumasan OPST. Dalam hal ini dilakukan sebuah penelitian guna mengetahui indikasi kerusakan OPST dan analisis perbaikan yang tepat guna mengembalikan performa dari OPST. Dalam mengidentifikasi kerusakan tersebut metode yang dilakukan adalah analisis trending spektrum menggunakan software omnitrend yang nilainya akan dibandingkan dengan hasil perhitungan bearing. Analisis tersebut menghasilkan bahwa terjadi vibrasi 1X RPM dikarenakan kerusakan pada ball bearing yang diakibatkan oleh pelumas bearing yang sudah keruh karena tercampur air. Untuk mengetahui masuknya air ke dalam oil chamber dilakukan dua cara yaitu percobaan hydrotest dan pengukuran clearances carbon ring seals. Setelah dilakukan dua percobaan tersebut didapatkan hasil penyebab masuknya air ke oil chamber karena overclearances pada carbon ring seals (vs 0.120-0.145 mm). Masalah yang terjadi ini mengakibatkan uap masuk ke penampungan oli sehingga pelumasan pada bearing tidak berjalan dengan baik sehingga terjadi kerusakan pada bearing. Setelah teridentifikasi kerusakannya, dilakukan pergantian komponen bearing inboard dan bearing outboard serta laping split face pada carbon ring seals. Setelah mengalami perbaikan vibrasi pada OPST kembali normal dari $3.72 \mathrm{~mm} / \mathrm{s}$ menjadi $0.93 \mathrm{~mm} / \mathrm{s}$.
\end{abstract}

Kata kunci: Bearing, Carbon Ring Seals, Turbin Uap, Vibrasi

\section{PENDAHULUAN}

Oil pump steam turbine (OPST) merupakan komponen penting karena menjadi penggerak dari main oil pump 32-K-101-P1. Main oil pump ini digunakan untuk mengalirkan lube oil ke main turbine dan kompresor. Dilihat dari fungsinya kehandalan kerja dari OPST harus terjaga dengan baik. Penelitian ini dilatarbelakangi oleh kenaikan vibrasi yang berulang dalam waktu yang pendek. Walaupun terdapat standby oil pump yang digerakan oleh motor listrik yang diaktifkan apabila terjadi kerusakan pada OPST tetapi kerusakan ini mengakibatkan kerugian karena motor listrik tersebut membutuhkan daya yang besar yaitu $22 \mathrm{~kW}$ dan jika terjadi pemadaman listrik dapat mengakibatkan penghentian proses produksi [1].

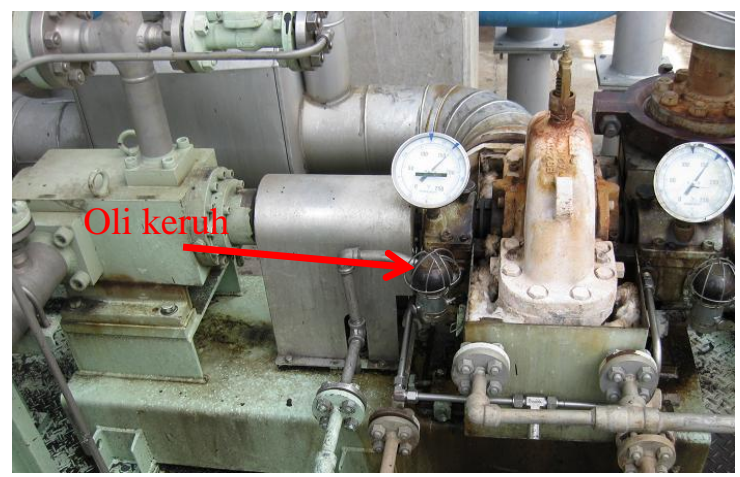

Gambar 1. Oil Pump Steam Turbine.

Pada Gambar 1 terlihat oli pada constant level sight-feed oiler sudah keruh. Keruhnya oli tersebut bisa disebabkan masuknya uap ke oil chamber atau bocornya water cooling jacket sehingga air pendingin oli masuk ke oil chamber. Tidak hanya oli yang keruh, indikasi kerusakan juga terjadi karena adanya kenaikan vibrasi dari batas alert high $(2.82 \mathrm{~mm} / \mathrm{s})$. Pengukuran vibrasi dilakukan menggunakan alat ukur VIBXpert II dan selanjutnya data vibrasi tersebut diproses untuk mencari trending vibrasi dan spektrum dengan menggunakan software Omnitrend sehingga 
dapat diketahui penyebab terjadinya kenaikan vibrasi tersebut. Terdapat banyak kemungkinan terjadinya kerusakan pada OPST, maka dari itu dibutuhkan penelitian ini sehingga dapat diketahui penyebab kerusakan OPST dan metode perbaikan yang tepat guna dalam memperbaiki dan mencegah terjadinya kerusakan yang berulang pada oil pump steam turbine.

\section{METODOLOGI}

Metodologi penelitian dijelaskan pada diagram alir di Gambar 2 dibawah ini yang terdiri dari langkah - langkah kerja sampai pada menyelesaikan penelitian.

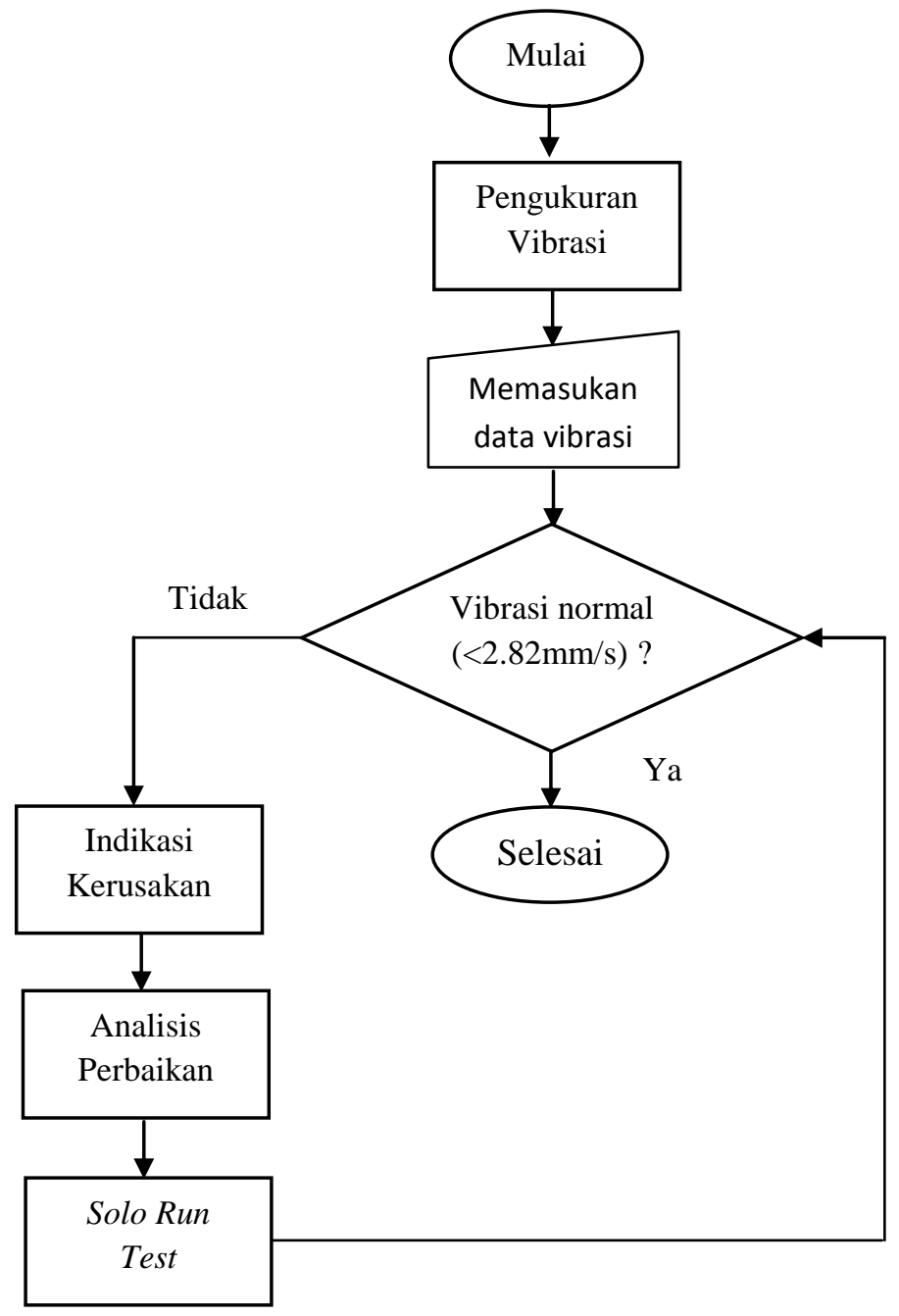

Gambar 2. Diagram alir metodologi.

Proses pengambilan data dilakukan dengan cara monitoring kondisi OPST secara rutin yaitu pengukuran kecepatan poros OPST, melihat kondisi lube oil, dan pengukuran vibrasi. Jika vibrasi tersebut melebihi batas alert high $(2.82 \mathrm{~mm} / \mathrm{s})$ data vibrasi tersebut diolah dengan software Omnitrend untuk melakukan analisis trending spektrum. selanjutnya menentukan frekuensi kerusakan bearing dengan melakukan perhitungan menggunakan persamaan frekuensi kerusakan bearing. Apabila hasil perhitungan menggunakan persamaan frekuensi kerusakan bearing berada pada kisaran $\mathrm{N}-10$ sampai dengan $\mathrm{N}+10$ yang nilainya disesuaikan dengan amplitudo spektrum maka bearing tersebut dapat dikatakan rusak sesuai dengan kategorinya [2]. Setelah diketahui kerusakan dilakukan analisis perbaikan dengan mengganti atau memperbaiki dan komponen yang rusak. Setelah selesai dilakukan perbaikan, dilakukan pengujian Solo Run Test untuk mengetahui nilai vibrasi OPST setelah perbaikan. Jika dibawah alert high penelitian dianggap selesai dan benar.

2.1. Analisis Trending Spektrum Vibrasi

Yang dimaksud dengan trending spektrum disini adalah usaha menemukan masalah dan penyebabnya dengan mengkaji pola perbandingan besarnya amplitudo vibrasi pada semua frekuensi yang mungkin terjadi. Analisis ini 
Norman Iskandar dkk., Analisis Kerusakan Dan Perbaikan Oil Pump Steam Turbine 32-K-101-P1-T Dalam Platforming Unit-Naphta Processing Unit (Npu)

digunakan untuk mendiagnosis sumber penyebab dominan vibrasi dari suatu mesin dan nantinya disesuaikan dengan Tabel 1. Pengukuran spektrum vibrasi ini biasanya dilakukan jika nilai vibrasi overall sudah relatif tinggi [2].

Tabel 1. Frekuensi Vibrasi dan Penyebabnya

\begin{tabular}{|c|c|}
\hline Frekuensi dalam bentuk RPM & Penyebab \\
\hline 1x RPM & $\begin{array}{c}\text { Un-balance } \\
\text { Excessive Bearing Clearance }\end{array}$ \\
\hline 2x RPM & Mechanical Looseness \\
\hline 3x RPM & Misalignment \\
\hline Less than 1x RPM & Oil Whirl (<1/2 RPM) \\
\hline Synchronous (A.C.Line Frequency) & Electrical Problems \\
\hline 2x Synchronous Frequency & Torques \\
\hline Many times RPM (Harmonically Related Freq.) & Bad Gears \\
& Aerodinamic Forces. \\
\hline High Frequency (Not Harmonically Related & Bad Anti-Friction Bearings \\
\hline
\end{tabular}

\subsection{Analisis Perhitungan Frekuensi Kerusakan Bearing}

Untuk menentukan kerusakan di bagian apa pada suatu bearing, maka perlu dilakukan perhitungan frekuensi kerusakan bearing yang selanjutnya disesuaikan dengan trending spektrum vibrasi. Adapun rumus yang digunakan adalah persamaan 1 - 4 [3].

$$
\begin{aligned}
& \text { BPFO }=\left(\frac{N b}{2}\right)\left(\frac{S}{60}\right)\left(1-\frac{B_{d} \cos \theta}{P_{d}}\right) \\
& \text { BPFI }=\left(\frac{N b}{2}\right)\left(\frac{S}{60}\right)\left(1+\frac{B_{d} \cos \theta}{P_{d}}\right) \\
& \text { FTF }=\left(\frac{1}{2}\right)\left(\frac{S}{60}\right)\left(1-\frac{B_{d} \cos \theta}{P_{d}}\right) \\
& \text { BSF }=\left(\frac{1}{2}\right)\left(\frac{S}{60}\right)\left(\frac{P_{d}}{B_{d}}\right)\left(1-\frac{B_{d} \cos \theta}{P_{d}}\right)^{2}
\end{aligned}
$$

dimana:

BPFO : Ball Pass Frequency of Outer Race $(\mathrm{Hz})$

BPFI : Ball Pass Frequency of Inner Race $(\mathrm{Hz})$

FTF : Fundamental Train Frequency $(\mathrm{Hz})$

BSF : Ball Pass Frequency $(\mathrm{Hz})$

$\mathrm{Nb} \quad$ : Number of balls

$\mathrm{S} \quad$ : Speed of rotor (RPM)

$\mathrm{Bd} \quad$ : Ball diameter $(\mathrm{mm})$

$\mathrm{Pd} \quad$ : Pitch diameter $(\mathrm{mm})$

$\theta \quad$ : Contact angle $\left({ }^{\circ}\right)$

\section{HASIL DAN PEMBAHASAN}

Berikut ini akan ditampilkan hasil analisis - analisis yang digunakan dalam mencari indikasi kerusakan yang terjadi pada Oil pump steam turbine (OPST).

\subsection{Pengambilan Data Vibrasi dan Analisis Trending Spektrum}

Data operasi yang digunakan untuk memulai analisis kerusakan pada turbin uap 32-K-101-P1-T adalah data vibrasi pada bearing outboard dan inboard dari tanggal 3 November 2015 - 25 Januari 2016. Alert high dari nilai vibrasinya adalah $2.82 \mathrm{~mm} / \mathrm{s}$ dan danger high nilai vibrasinya adalah $7.07 \mathrm{~mm} / \mathrm{s}$. seperti dijelaskan pada tabel 2 .

Tabel 2. Data Vibrasi Oil Pump Steam Turbine

\begin{tabular}{|c|c|c|c|c|c|c|}
\hline Pengukuran & $\mathbf{2 5 / 1 / 2 0 1 6}$ & $\mathbf{1 4 / 1 / 2 0 1 6}$ & $\mathbf{3 1 / 1 2 / 2 0 1 6}$ & $\mathbf{1 7 / 1 2 / 2 0 1 5}$ & $\mathbf{1 9 / 1 1 / 2 0 1 5}$ & $\mathbf{0 3 / 1 1 / 2 0 1 5}$ \\
\hline TRB-OB-A & 3.72 & 1.36 & 1.38 & 1.78 & 1.67 & 2.05 \\
\hline TRB-OB-H & 4.81 & 1.17 & 2.15 & 2.38 & 1.56 & 3.67 \\
\hline TRB-OB-V & 5.02 & 2.54 & 2.77 & 2.91 & 2.76 & 2.65 \\
\hline TRB-IB-A & 3.82 & - & - & - & - & - \\
\hline
\end{tabular}




\begin{tabular}{|c|c|c|c|c|c|c|}
\hline TRB-IB-H & 3.97 & 2.90 & 1.8 & 2.11 & 1.74 & 2.95 \\
\hline TRB-IB-V & 4.15 & 2.42 & 2.72 & 2.65 & 2.59 & 2.6 \\
\hline PMP-OB-A & - & 0.75 & 0.7 & 0.65 & 0.73 & 0.53 \\
\hline PMP-OB-H & - & 0.27 & 0.3 & 0.33 & 0.37 & 0.37 \\
\hline PMP-OB-A & - & 0.75 & 0.96 & 0.63 & 0.88 & 0.73 \\
\hline PMP-IB-A & - & 0.66 & 0.7 & 0.68 & 0.67 & 0.67 \\
\hline PMP-IB-H & - & 0.77 & 0.36 & 0.33 & 0.9 & 0.81 \\
\hline PMP-IB-V & - & 0.94 & 0.81 & 0.62 & 0.71 & 1.07 \\
\hline RPM & 2950 & 2950 & 2950 & 2950 & 2950 & 2950 \\
\hline NOTE & $\begin{array}{c}\text { Oil di Outboard } \\
\text { Bearing keruh }\end{array}$ & & & & $\begin{array}{c}\text { Setelah } \\
\text { pembersihan oli } \\
\text { di Outboard dan } \\
\text { Inboard }\end{array}$ \\
\hline
\end{tabular}

Dari data tersebut diketahui bahwa terjadi kenaikan vibrasi pada OPST. Dimana kenaikan tersebut melebihi batas alert high $(2.82 \mathrm{~mm} / \mathrm{s})$. Selanjutnya data vibrasi diolah menggunakan software Omnitrend untuk mencari trending spektrum vibrasi. Yang dimaksud dengan analisis spektrum disini adalah usaha menemukan masalah dan penyebabnya dengan mengkaji pola perbandingan besarnya amplitudo vibrasi pada semua frekuensi yang mungkin terjadi. Adapun untuk gambar spektrum vibrasi yang merupakan hasil perubahan dari sinyal getaran ke sinyal elektrik dapat dilihat pada gambar di bawah ini.

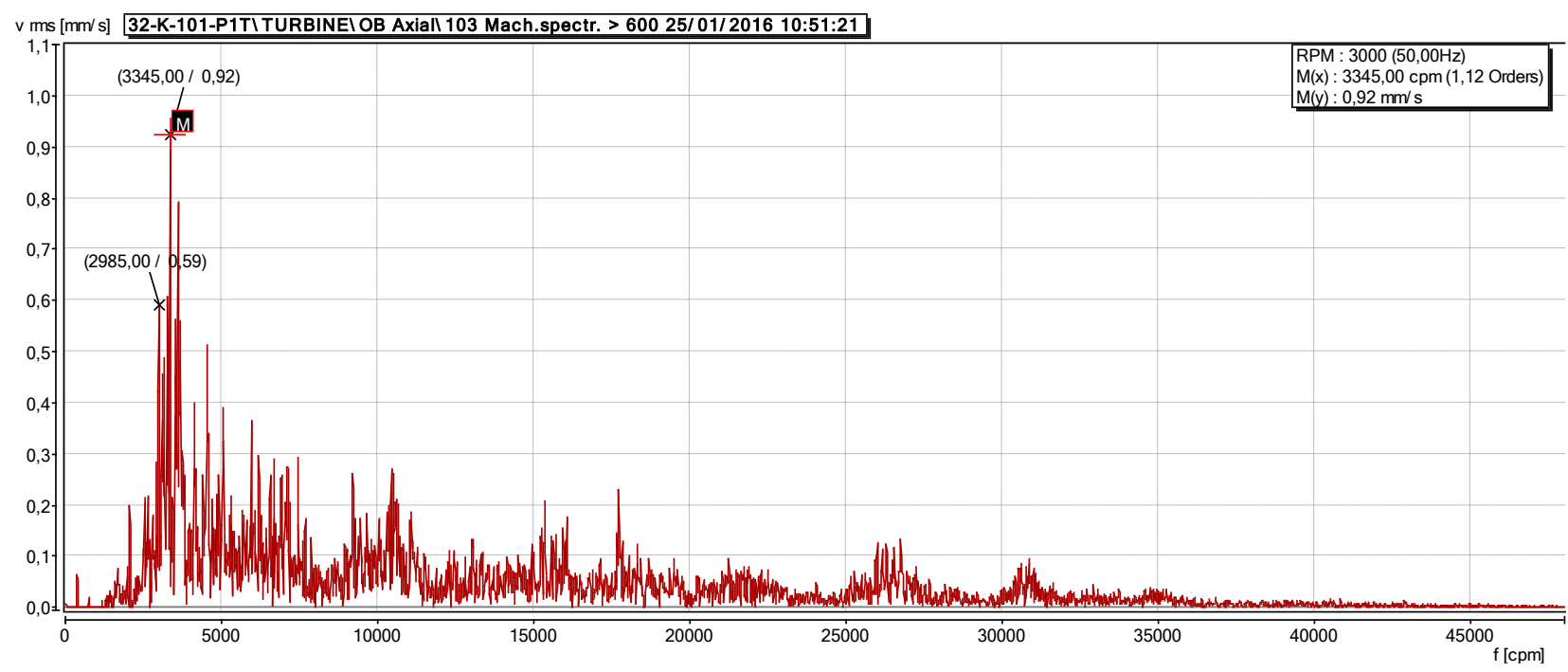

Gambar 3. Spektrum vibrasi pada posisi outboard aksial turbin 32-K-101-P1.

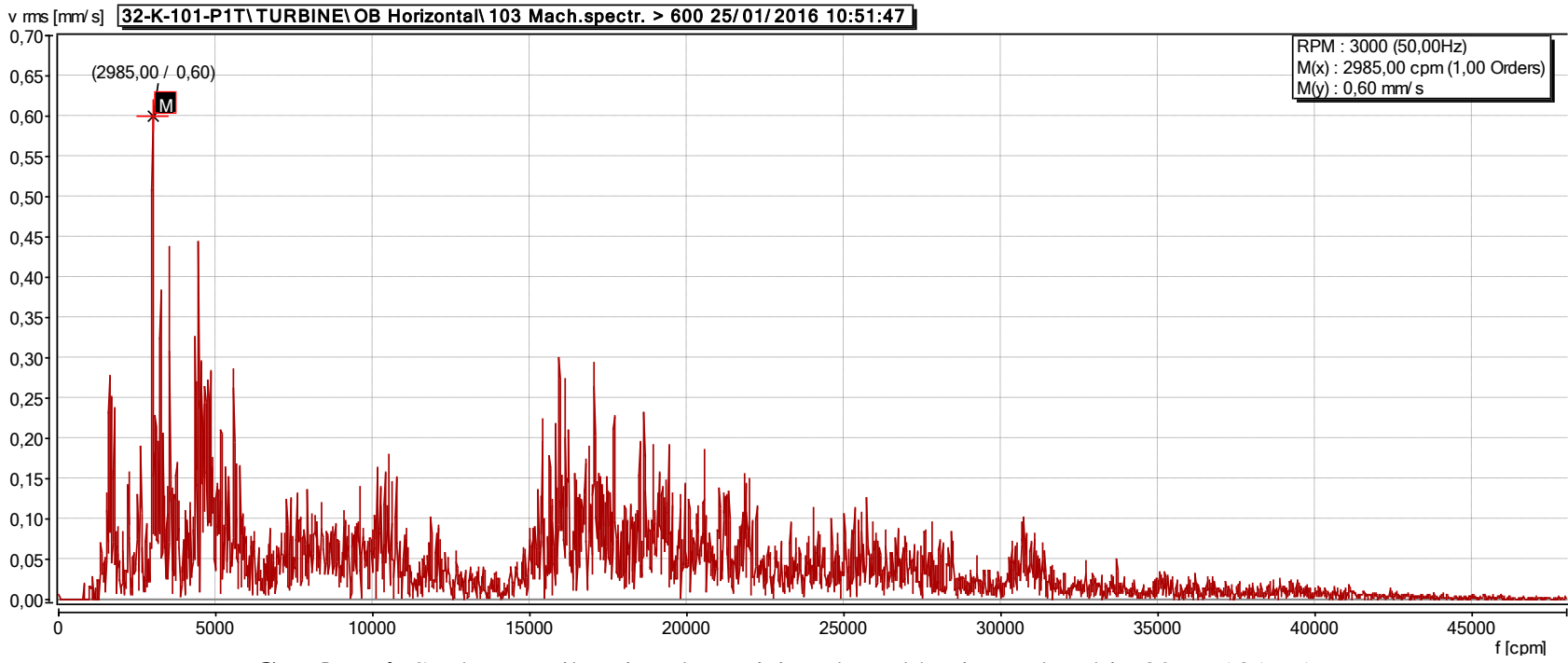

Gambar 4. Spektrum vibrasi pada posisi outboard horizontal turbin 32-K-101-P1. 
Norman Iskandar dkk., Analisis Kerusakan Dan Perbaikan Oil Pump Steam Turbine 32-K-101-P1-T Dalam Platforming Unit-Naphta Processing Unit (Npu)

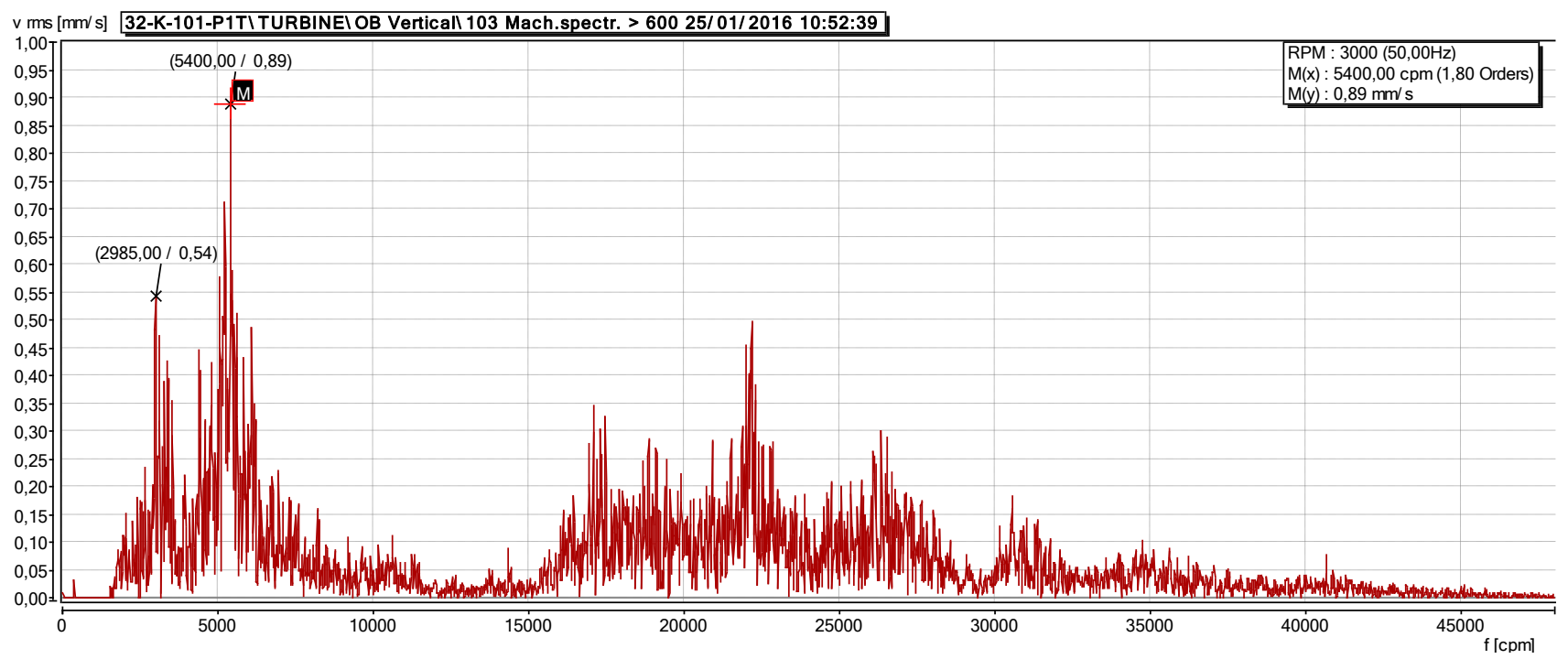

Gambar 5. Spektrum vibrasi pada posisi outboard vertikal turbin 32-K-101-P1.

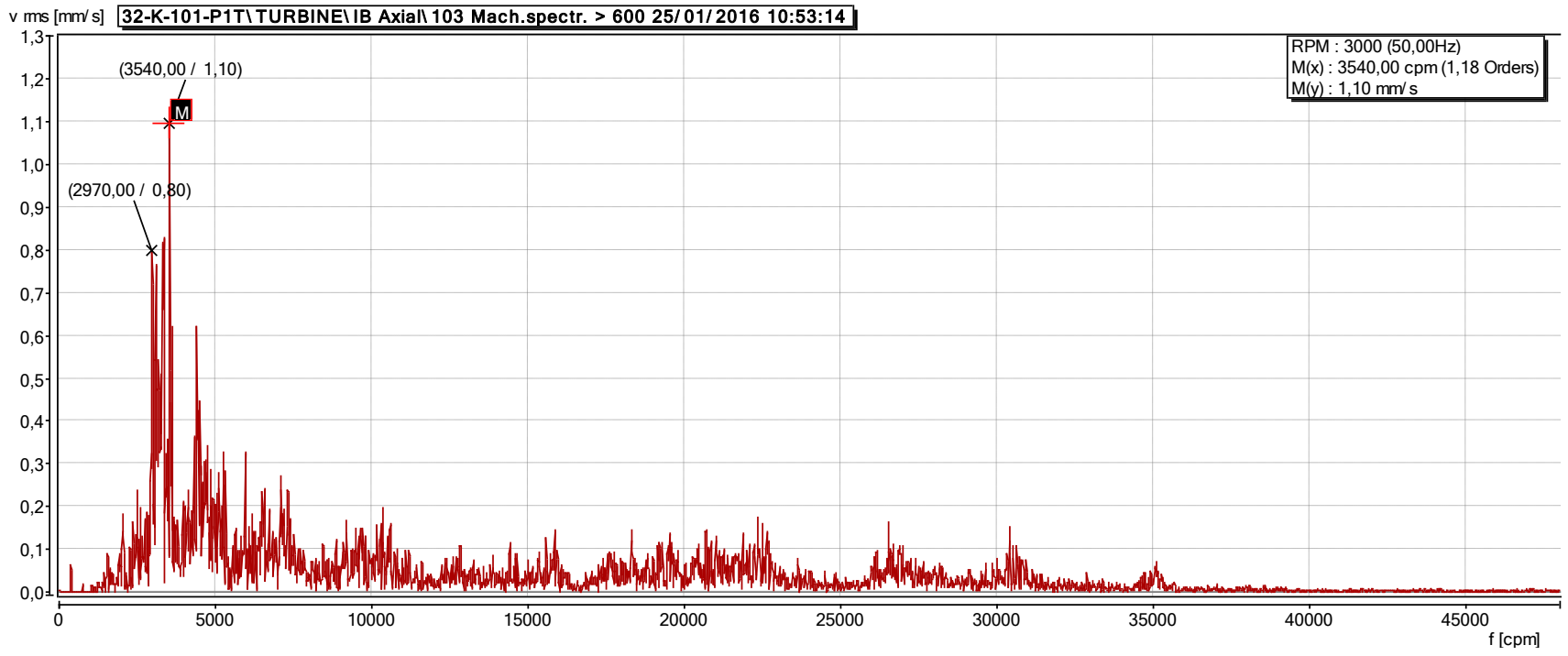

Gambar 6. Spektrum vibrasi pada posisi inboard aksial turbin 32-K-101-P1.

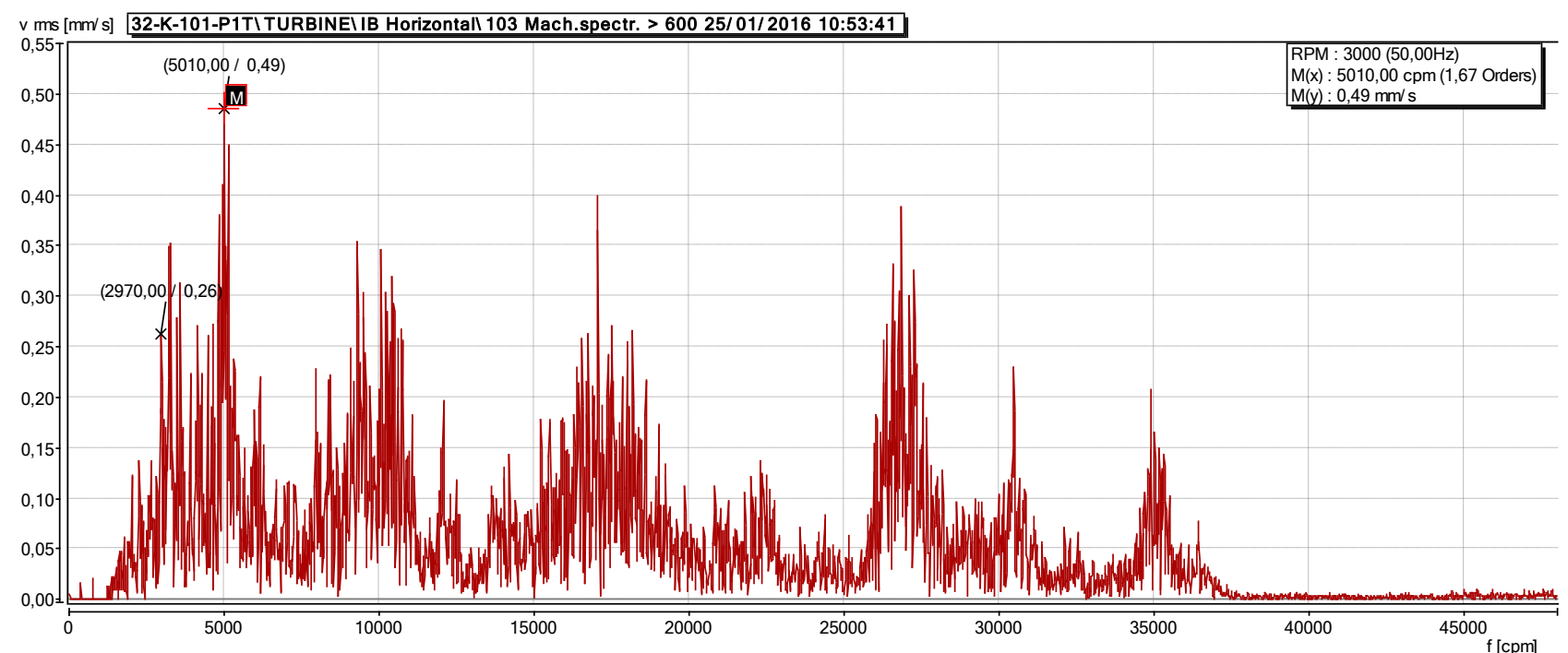

Gambar 7. Spektrum vibrasi pada posisi inboard horizontal turbin 32-K-101-P1. 


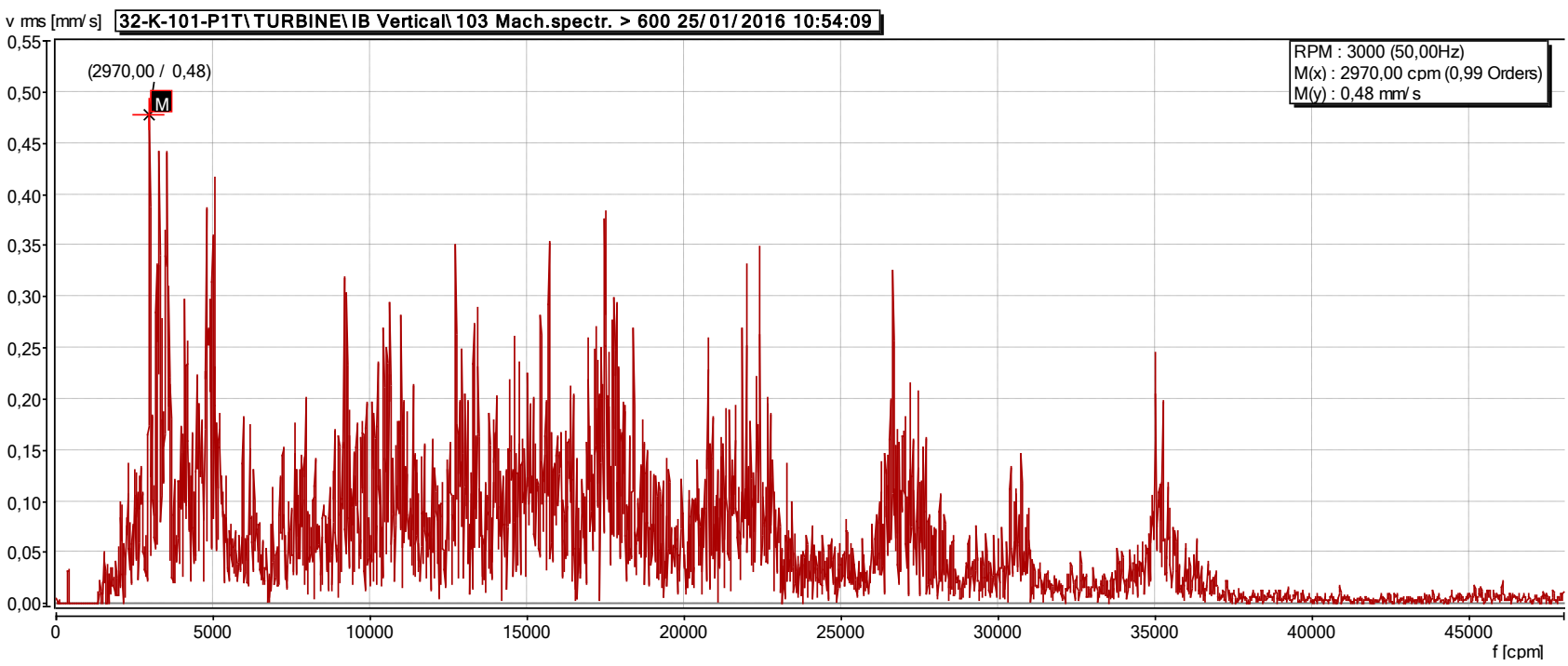

Gambar 8. Spektrum vibrasi pada posisi inboard vertikal turbin 32-K-101-P1.

Rata - rata peak (puncak spektrum) vibrasi dari gambar diatas terjadi pada $50 \mathrm{~Hz}(1 \mathrm{~Hz}=1$ siklus per detik) dan terdapat banyak noise. Karena motor juga berputar dengan kecepatan $50 \mathrm{~Hz}$ (3000 RPM/60) maka dapat dikatakan bahwa terjadi vibrasi $1 \mathrm{x}$ pada turbin uap 32-K-101-P1. Sesuai dengan tabel 1 maka terjadi unbalance atau excessive clearance pada bearing.

\subsection{Perhitungan Frekuensi Kerusakan Bearing}

Untuk menentukan kerusakan di suatu bagian pada bearing, maka perlu dilakukan perhitungan frekuensi kerusakan bearing yang selanjutnya disesuaikan dengan data spektrum vibrasi. Perhitungan dilakukan dengan menggunakan persamaan $1-4$. Jika pada hasil perhitungan menunjukan nilai BPFO sama dengan amplitudo pada spektrum vibrasi maka terjadi kerusakan pada outer ring Bearing. Jika nilai BPFI sama dengan amplitudo pada spektrum vibrasi maka yang rusak adalah inner ring bearing. Jika nilai FTF sama dengan amplitudo pada spektrum vibrasi maka yang rusak adalah cage ball bearing. Jika nilai BSF sama dengan amplitudo pada spektrum vibrasi maka terjadi kerusakan pada ball bearing [4].

Adapun parameternya didapatkan dari katalog bearing skf 6307 NR/C3 dan manual book turbin uap. Dari katalog bearing skf 6307 NR/C3 didapatkan jumlah bola bearing 8 buah, diameter bola bearing 13,55 mm, diameter pitch $57,5 \mathrm{~mm}$, dan sudut kontak sebesar $0^{\circ}$. dari manual book didapatkan nilai kecepatan rotor OPST sebesar 2950 rpm. Setelah dilakukan perhitungan didapatkan nilai BPFO $151.4 \mathrm{~Hz}$, BPFI $241.92 \mathrm{~Hz}$, FTF $18.93 \mathrm{~Hz}$, dan BSF 60.92 $\mathrm{Hz}$.

Jadi, setelah dilakukan perhitungan frekuensi kerusakan bearing dapat disimpulkan bahwa kerusakan bearing terletak pada ball bearing saja. karena nilai perhitungan BSF $(60.92 \mathrm{~Hz})$ berada dalam range $10 \%$ dari nilai rata - rata amplitudo trending spektrum. Karena bola bearing sudah dinyatakan rusak, maka bearing 6307 yang digunakan OPST pada penelitian kali ini harus diganti.

\subsection{Indikasi Kerusakan}

Setelah melakukan overhaul, didapatkan bahwa penyebab kerusakan bearing adalah oli yang keruh. Oli berubah menjadi lumpur karena tercampur air. Ada indikasi - indikasi yang menyebabkan keruhnya oli. Pertama adalah bocornya water cooling jacket dan kedua adalah clearances dari carbon ring seal yang membesar. Setelah melakukan percobaan hydrotest, didapatkan kesimpulan bahwa water cooling jacket tidak mengalami kebocoran. Dan pengujian terakhir adalah melakukan pengukuran clearances pada carbon ring seals dengan menggunakan feeler sebagai alat ukur. Setelah dilakukan pengukurun didapatkan ukuruan diameter clearances pada bearing adalah $0.61 \mathrm{~mm}$ yang artinya adalah clearances tersebut melewati batas tolerasi yaitu $0.120 \mathrm{~mm}-0.145 \mathrm{~mm} .[1]$

\subsection{Analisis Perbaikan}

Setelah dilakukan diagnosis kerusakan diambil langkah - langkah perbaikan untuk mengembalikan performa turbin uap 32-K-101-P1-T yaitu mengganti bearing inboard dan bearing outboard serta mengurangi diameter dalam dari carbon ring seals dengan cara laping split faces.

\section{KESIMPULAN}

Melihat data yang diperoleh dari pengambilan data dan pembahasan analisis yang telah dilakukan, dapat diambil beberapa kesimpulan sebagai berikut bahwa kerusakan pada peralatan berputar, dalam hal ini kerusakan bearing pada Oil pump steam turbine (OPST) dapat dideteksi dengan bantuan spektrum vibrasi. Indikasi awal kerusakan bearing 
ditandai dengan munculnya spektrum pada frekuensi ultrasonic dan lama-kelamaan akan menuju ke frekuensi rendah apabila bearing sudah masuk dalam kategori rusak.

Setelah dilakukan analisis trending spektrum vibrasi didapati hasil dari penyebab tingginya vibrasi OPST adalah rusaknya bola bearing di outboard dan inboard. Rusaknya bearing dikarenakan lube oil terkontaminasi karena tercampur oleh uap. Uap masuk ke oil chamber karena clearances pada carbon ring seals diatas batas toleransi sebesar $0.61 \mathrm{~mm}$ (vs max $0.120-0.145 \mathrm{~mm}$ ). Setelah dilakukan perbaikan dengan cara laping split face carbon ring dan mengganti bearing outboard dan bearing inboard didapatkan vibrasi radial (horizontal dan vertikal) dan aksial pada saat solo run dibawah alert high $(2.82 \mathrm{~mm} / \mathrm{s})$.

\section{REFERENSI}

[1] Ebara Group. 2003. Manual Book Steam Turbine 32-K-101-P1-T. Elliott Turbomachinery Co, Inc.

[2] Hardjono, R. N., Sukmadi T., Karnoto. 2013. Pemanfaatan Spektrum Vibrasi Untuk Mengindikasikan Kerusakan Motor Induksi Di Pltu Indramayu 3 X 330 MW. Transient Vol. 2. Universitas Diponegoro..

[3] Graney, Brian P., Starry Ken. 2011. Rolling Element Bearing Analysis. ME Technical Paper. The American Society for Nondesdructive Testing Inc.

[4] Juvinall, Robert, Marshek, Kurt. 2011. Fundamentals of Machine Components Design. John Wiley \& Sons, Inc. University of Michigan. 